Bond University

Research Repository

\title{
All the same but different: Understanding family enterprise heterogeneity
}

Moores, Ken; Parris, Denise; Newbert, Scott; Craig, Justin B

Published in:

The Palgrave Handbook of Heterogeneity among Family Firms

DOI:

10.1007/978-3-319-77676-7_21

Licence:

Unspecified

Link to output in Bond University research repository.

Recommended citation(APA):

Moores, K., Parris, D., Newbert, S., \& Craig, J. B. (2018). All the same but different: Understanding family enterprise heterogeneity. In E. Memili, \& C. Dibrell (Eds.), The Palgrave Handbook of Heterogeneity among Family Firms (pp. 557-587). Palgrave Macmillan. https://doi.org/10.1007/978-3-319-77676-7_21

\section{General rights}

Copyright and moral rights for the publications made accessible in the public portal are retained by the authors and/or other copyright owners and it is a condition of accessing publications that users recognise and abide by the legal requirements associated with these rights.

For more information, or if you believe that this document breaches copyright, please contact the Bond University research repository coordinator 
All the Same but Different: Understanding Family Enterprise Heterogeneity

\author{
Ken Moores Ph.D. D.Bus. \\ Emeritus Professor: Bond University \\ Executive Chairman: Moores Family Enterprises \\ ken@mooresfamilyenterprises.com.au \\ Denise Linda Parris \\ Assistant Professor \\ The W. A. Franke College of Business \\ Northern Arizona University \\ P.O. Box 15066 \\ Flagstaff, AZ. 86011-5066 \\ deniselparris@gmail.com \\ Scott L. Newbert \\ Lawrence N. Field Chair in Entrepreneurship \\ Professor of Management \\ Zicklin School of Business \\ Baruch College \\ New York, NY. 10010 \\ Justin B. Craig \\ Clinical Professor of Family Enterprise and Director \\ Center for Family Enterprises \\ Kellogg School of Management \\ Northwestern University \\ Evanston, IL. 60208 \\ justin.craig@kellogg.northwestern.edu
}




\begin{abstract}
We explore heterogeneity in family firms from its core antecedents: the presence of family and their pursuit of dual logics in decision-making and position servant leadership, stewardship and trust as emanating core philosophies, which manifest in an organization-level (AGES) and individual-level (SAGE) framework, and ultimately skill-sets that are all unique to family firms but which also serve to differentiate within this class of firms. Our conceptual metamodel of family enterprise heterogeneity serves as a guide for family firms to identify and understand the perception versus reality of their heterogeneity, and then enables the development of strategies to maintain organizational culture and/or evaluate organizational change.
\end{abstract}

\title{
Keywords: family enterprise heterogeneity; servant leadership; stewardship; trust; mindset; skill-set
}

\section{Introduction}

The community of family business scholars has been pursuing what is considered normal science (Kuhn, 1970) for decades now. Initially, family business scholars focused on the difference between family firms and nonfamily firms. In so doing, they tended to assume homogeneity among family firms to generate generalizable findings. However, it did not take long for this assumption to be questioned. Researchers began to identify distinct types of family firms; one of the earliest to question homogeneity was Ward (1987), who identified business first, family first, and business family enterprises. The prevailing paradigm informing the study of family business has become the 3-circle Venn diagram, also called the F-O-M Venn diagram, which illustrates the interconnecting types of stakeholders in family firms: family, owners, and managers (Moores, 2009). These three types have subsequently been confirmed empirically (Basco \& Rodriguez, 
2009). Others too (e.g., Dekker, Lybaert, Steijers, Depaire, \& Mercken, 2012; Sharma \& Nordqvist, 2008; Stewart \& Hitt, 2012) have distilled further differences within the class of family firms.

These differences highlight the heterogeneity of family firms and stress the need for our theories to recognize this important feature. At the same time, accommodating too much heterogeneity risks generalizability. Accordingly, the incorporation of heterogeneity is arguably best achieved at abstract levels from which different theoretical and practical consequences can be highlighted. The paradigm of three intersecting systems, the F-O-M Venn diagram, provides an ideal basis to introduce such heterogeneity. Specifically, within-class differences can be at the family, owner, or manager levels.

The contribution of this chapter is the exploration of heterogeneity in family firms from its core antecedents: the presence of family and their pursuit of dual logics in decision-making. These features define a mindset that gives rise to philosophies, frameworks, and ultimately skill-sets that are all unique to family firms but which also serve to differentiate within this class of firms. These elements coalesce as a conceptual model, as presented in Figure 1. The structure of this chapter commences with a brief overview of the family-business-paradigm underpinning of a dual-logic mindset, and where and how heterogeneity can be introduced. Thereafter we present the central philosophies of servant leadership, trust, and stewardship, from which further differences can emerge. We then refer to frameworks at both organizational (AGES) and individual (SAGE) levels that isolate the observable differences both between family and nonfamily firms and within our class of firms. The outcomes of the mindsets, philosophies, and frameworks we examine require family firms to have both family and business skill-sets to lead, govern, innovate, and adopt. Finally, we conclude with how the conceptual meta-model of family enterprise heterogeneity can 
be used as guide for family firms to identify and understand the perception versus reality of their heterogeneity, and then to develop strategies to maintain organizational culture or evaluate organizational change.

\section{INSERT FIGURE 1 HERE}

\section{The 3-Circle Paradigm Underpins the Dual-Logic Mindset}

According to Kuhn (1970), the development and evolution of scientific disciplines follows identifiable paths (Table 1). Aligned with this notion, an emerging discipline seeking to explain the domain of family business has been developing and evolving over recent decades. Common processes exist across disciplines regarding how bodies of understanding are built cumulatively (Christensen, 2006). To gain legitimacy, emerging disciplines borrow from more established fields to advance understanding of their phenomena of interest (Born, 1956). Scholars within these communities engage in theoretical integration to facilitate evolution of knowledge and understanding, thereby enabling burgeoning fields to progress from pre-paradigmatic status to scientific consensus (Moores, 2009).

\section{INSERT TABLE 1 HERE}

Moreover, to progress disciplinary evolution, scholars often make facilitative assumptions about their phenomena of interest. The difference between their focal phenomenon and those for which theoretical explanations already exist often motivates the search for new knowledge. To assist these intellectual endeavors, the notion of difference from others, but similarity among our

focal interest, helps to progress knowledge. This truth indeed stimulated much of the early inquiry in family business, where scholars sought to explain the difference of family-owned firms from 
their nonfamily counterparts. These inquiries were founded on the assumption that all family firms at a certain level of abstraction were similar, or homogeneous.

As noted earlier, it did not take long for the homogeneity of family firms to be questioned. Ward (1987) was the first to identify three distinct types of family firms: business first, family first, and business family enterprises, a typology subsequently confirmed empirically by Basco and Rodriquez (2009). These differences among family firms highlights the heterogeneity of such firms and the need for our theories to recognize this reality. Specifically, the presence of both economic (efficiency) and non-economic (family welfare) objectives calls for theoretical analyses that acknowledge tradeoffs (Yupitun, 2008). Because heterogeneity exists among family firms (Chrisman \& Patel, 2012; Chua, Chrisman, Steier, \& Rau, 2012), any theory of the family firm must be able not only to distinguish family from nonfamily firms but also to explain variations among family firms.

Calls to endogenize the family in the theory of the firm (Munteau, Phan, \& Butler, 2008) bring with them heightened prospects for identifying dimensions of heterogeneity in this domain. First, there are implications for how and in what ways to include "family" in the theory of the firm and, because of this, the objective function of the firm will need to be viewed differently. The question then arises as to how to introduce/embed "family" into the theory (Aldrich \& Cliff, 2003). Second, because families are acknowledged as having multiple objectives (Sharma, Chrisman, \& Chua, 1997), inclusion of "family" would imply that the concept of the firm primarily as a production function must be expanded. No longer can theory be based on a single objective to be maximized; instead, it must embrace the presence of multiple objectives. Neither a business (value maximization) objective nor a family (harmony maximization) objective reflects adequately the underlying reality of the presence of both these that need to be optimized. 
Though the behavioral theory of the firm suggests that all managers pursue both economic and non-economic goals (Cyert \& March, 1963) because the family serves as a dominant coalition in family firms, scholars agree that the family will generally pursue familycentered noneconomic goals that mainly benefit themselves (Chua, Chrisman, \& DeMassis, 2015). In line with this, although family firms generally struggle to balance their desire to increase the business's financial viability with their objective of elevating the family's social capital (often referred to as socioemotional wealth), early studies examining decision-making in family firms found that family owners tend to prioritize the latter over the former (Kets de Vries, 1993).

While the empirical literature has routinely upheld this pattern of prioritization (see Berrone, Cruz, \& Gomez-Mejia (2012) for a full review), recent research suggests that the picture might not be as simple as thought previously. That is, what were historically considered tradeoffs between competing economic and non-economic logics (Pache \& Santos, 2013) may not be tradeoffs at all. Indeed, Martin and Gomez-Mejia (2016) argue that although a family’s affective goals may dominate its financial goals, there may often be times when the two objectives overlap. These authors theorize, further, that family owners may find that achieving one goal facilitates their ability to achieve the other.

If Martin and Gomez-Mejia (2016) are accurate, then what have been viewed as competing logics in nonfamily firms may actually be complementary logics. Interestingly, this is precisely how Adam Smith viewed the pursuit of economic and non-economic goals. While Smith did argue in The Wealth of Nations that business owners ought to first consider their economic interests rationally (Smith, 1994), he argued earlier, in The Theory of the Moral Sentiments, that one should always avoid causing harm to others, particularly those with whom 
one is intimately related, such as family members (Smith, 1976). In such cases, Smith advocated for "irrational" motives for decision-making, including love and benevolence (Nieli, 1986). Thus, what seems unique about family firms compared to their nonfamily counterparts is that they appear to implement the full measure of Smith's thought in their day-to-day decisionmaking. According to Miller and LeBreton-Miller (2014, p. 717), this "extended" view of family business, in which "rewards accrue not merely to the family, but to other stakeholders as well, [a]nd the benefits to the business may be of more of a long-term nature" better reflects the phenomenon than the current "restricted" view.

Finally, expansion of the concept of the firm in this family-centric driven way is likely to render the "entrenched paradigms across disciplines that notoriously underestimate the role of the family in economic enterprise and organizational behaviour more generally" (Muntean, Phan, \& Butler, 2008, p. 6) less relevant to evolution of the discipline. Moreover, theories that address aspects of social capital— " features of social organization such as networks, norms, and social trust that can facilitate coordination and cooperation for mutual benefit', (Putnam, 1995, p. 66) and institutionalism - and how organizational structure conforms to expectations about appropriate design and function (DiMaggio \& Powell, 1983) will likely be more salient in our future endeavors to build robust theory of business families. The 3-circle Venn diagram and the dual-logic mindset reflect the heterogeneity in family firms.

Origin of Heterogeneity 1: When we consider the family in the 3-circles (F-O-M) paradigm as a lens, the family system morphs from a single family to a constellation of families over time. With this comes, inevitably, diversity along many dimensions, including but not limited to commitment to and engagement with the business, cultural differences as family members marry into families with different cultural origins, and expectations of what it means to 
be a part of a business family. Likewise, as ownership transitions over time, there are likely considerable differences among owners in how each interprets the meaning of ownership. Some may see ownership as a right while others consider it a privilege; some may attribute higher value to the psychological attachment rather than to any economic benefits ownership delivers.

In other words, it is inevitable that individuals will vary on the level of utility they receive from ownership. Different labels have been introduced to capture ownership types, including managing owners, passive owners, governing owners, and engaged owners. Ownership type has also been categorized by types of shares owned, and this will depend on jurisdiction (e.g., A shares vs B shares). Similarly, because in our interpretation of the three circles we consider managers as those charged with managing on behalf of owners (others label this domain as 'business' or 'management'), there is likely some contrast among how appointed managers discharge their duties as managers. There will likely be, for example, considerable differences of opinion related to strategic direction of operating entities, how core and non-core assets are managed, how philanthropic activities are orchestrated, and how managers are prepared and monitored.

Origin of Heterogeneity 2: Further, using the dual-logic mindset as a lens to highlight heterogeneity, as the family and the business evolve it is inevitable that there will be differences related to the role that the enterprise plays with the family and vice-versa (i.e., the family first/business first paradox). Relatedly, the degree to which the family has a social versus economic purpose will be potentially contentious, particularly if the family is fortunate to enjoy sustained success. Variance may emerge related to, for example, the societal responsibilities of the business (or as one family positions this: "being a vehicle for good"). There may also emerge differences related to economic metrics concerned with, for instance, growth and risk. 
Understanding different logics also highlights the benefit of the business being an economic vehicle useful for developing social capital, connection and commitment to the broader community and, perhaps as important, sense of familial unity.

\section{The 3-Circle Paradigm and Dual-Logics Mindset Underpin Philosophical Differences}

Building from the paradigmatic and logics foundation presented above, to present divergent philosophies emergent within family enterprises, we utilized Greenleaf’s (1977) servant leadership framework coupled with stewardship theory (Davis, Schoorman, \& Donaldson, 1997) and the most cited models of trust (Mayer, Davis, \& Schoorman, 1995; Schoorman, Mayer, \& Davis, 2007). We introduce these three lenses as philosophies rather than theories, and employ them for two reasons. First, each acknowledges family firms' unique ethical values compared to nonfamily firms, including: their focus on fairness, respect, caring, stewardship, loyalty (Blodgett, Dumas, \& Zanzi, 2011; Duh, Belak, \& Milfelner, 2010), the wellbeing of employees (Miller \& Le Breton-Miller, 2005), and collectivist firm culture (Bingham, Dyer, Smith, \& Adams, 2011; Vallejo \& Langa, 2010; Ward, 1987). Second, we found additional support for their appropriability by content analyzing 48 'philosophy of management' papers submitted by Northwestern University Kellogg School of Management MBA students (from 12 different countries) in a family business class. The students were tasked with developing an individual approach (i.e., philosophy) to leadership/management; when reviewed, the dominant themes loaded on the dimensions of servant leadership, stewardship, and/or trust. In addition to aligning with themes in the broader family business literature, we have tentative empirical support for introducing each and, taken together, consider these rich philosophical anchors (see Figure 2: Philosophies Emergent within Family Enterprises). Next, we will provide 
a deeper understand of each philosophy and how each can further inform the concept of heterogeneity in family firms.

\section{INSERT FIGURE 2 HERE}

\section{Servant Leadership}

Servant leadership is linked to ethics, virtues, and morality (Graham, 1991; Lanctot \& Irving, 2010; Parolini, Patterson, \& Winston, 2009; Parris \& Welty Peachey, 2013a; Russell, 2001; Whetstone, 2002). Greenleaf introduced servant leadership into the organizational context with three foundational essays: The Servant as Leader (1970), The Institution as Servant (1972a), and Trustees as Servants (1972b). Servant leaders focus on building a loving and caring community, generating a shared vision for helping others, and creating the freedom and resources for employees to become servants themselves (Parris \& Welty Peachey, 2012), as their primary motivation is to serve others (Greenleaf, 1977; Sendjaya \& Sarros, 2002). Aligned with Greenleaf's (1977) warning that servant leadership would be difficult to operationalize, theoretical development of this construct has been slow partially because it is more than just a management technique but a way of life that begins with "the natural feeling that one wants to serve, to serve first'” (p. 7). A systematic literature review of empirical studies on servant leadership across organizational contexts, cultures, and themes by Parris and Welty Peachey (2013a) revealed it is a viable leadership theory that helps organizations, improves the well-being of employees, and can increase overall effectiveness of individuals and teams.

Servant leadership is a multidimensional construct where the leader places the good of those being led over their own self-interest, emphasizes employee development, displays stewardship of organizational resources, builds community, and practices empathy, humility, and 
authenticity (Barbuto \& Wheeler, 2006; Ehrhart, 2004; Laub, 1999; Liden, Wayne, Zhao, \& Henderson, 2008; Spears, 1995; Van Dierendonck \& Nuijten, 2011). To more efficiently contextualize how the dimensions of servant leadership relate across the vast family business landscape, we utilized Barbuto and Wheeler's (2006) Servant Leadership Questionnaire (SLQ). The SLQ identifies five distinct behaviors: altruistic calling (a desire to make a positive difference in others' lives); emotional healing (fostering spiritual recovery from hardship or trauma); wisdom (an awareness of surroundings and anticipation of consequence); persuasive mapping (influencing others using sound reasoning and mental frameworks to conceptualize greater possibilities); and organizational stewardship (taking an ethical responsibility for the well-being of the organization and society). Before using servant leadership to interpret heterogeneity in family enterprises, it is important to consider the driving foundations of each of the five SLQ behaviors.

Altruistic calling. Highly distinctive to servant leadership is the willingness to sacrifice self-interests for the sake of others based on the desire to improve others' lives (Barbuto \& Wheeler, 2002, 2006; Beck, 2014). One of the core issues differentiating the transformational leader from the servant leader is intent (Bass, 2000). Altruism, the motivation to increase another person's welfare, is at the core of a servant-first leadership paradigm; it is contrasted from a other approaches where a leader will serve others only after leadership has been established, because of egoism, or a need to increase one's own personal interests (Parris \& Welty Peachey, 2012). These leadership paradigms are opposites. Servant leadership goes beyond knowledge, skills, and abilities typically associated with leadership roles by requiring an internal transformation where the will to make life better for others and society is the primary motivation and becomes part of one's self-construction (Parris \& Welty Peachey, 2012). 
Emotional healing. Aligned with helping others first, a servant leader is committed and skilled at practicing empathy, listening, and healing, which enables them to foster spiritual recovery from hardship or trauma. In being empathic the servant leader strives to accept and understand others, never rejecting them, but occasionally refusing to recognize their performance as good enough. As a great listener, a servant leader automatically responds to any problem by listening receptively to what is said, which allows them to identify the will of the group and help clarify that will. A servant leader embraces the healing power of service by recognizing that as human beings employees can make themselves and others 'whole' (Parris \& Welty Peachey, 2013b). Implicit in the relationship between servant leader and the led is an understanding that the search for wholeness is shared (Greenleaf, 1977). Servant leaders are adept at creating safe environments in both formal and informal settings for employees to share personal and professional issues (Parris \& Welty Peachey, 2013b). A safe environment based on the healing power of service improves employees' well-being (Black, 2010; Jaramillo, Grisaffe, Chonko, \& Roberts, 2009a, 2009b; Neubert, Kacmar, Carlson, Chonko, \& Roberts, 2008) and increases organizational commitment (Cerit, 2010; Hale \& Fields, 2007; Hamilton \& Bean 2005; Han, Kakabadse, \& Kakabadse, 2010; Pekerti \& Sendjaya, 2010). By placing a high priority on the holistic development of employees, servant leaders create a safe environment and positive organizational culture (Ehrhart, 2004; Liden et al., 2008) where those who experience personal trauma will turn to the leaders for support (Barbuto \& Wheeler, 2006). Empathy, along with the self-awareness to understand, experience, and predict the feelings of others, is a servant leadership skill that can be developed and nurtured.

Wisdom. Servant leaders demonstrate self-awareness by viewing situations holistically and using foresight_-intuitively understanding past lessons, present realities, and the likely 
outcomes of decisions (Parris \& Welty Peachey, 2013a, 2013b; Spears, 1998). Kant (1978) and Plato (1945), defined wisdom as the combination of awareness and foresight; similarly, Barbuto and Wheeler (2006) defined wisdom as the blend of knowledge and utility. When these two characteristics are combined, leaders are astute at picking up cues in the environment and understanding proactively the implications of an action. Servant leaders high in wisdom are observant and anticipate outcomes well, enabling them to mesh applied knowledge and informed experience to make optimally altruistic choices (Bierly, Kessler, \& Christensen, 2000).

Persuasive mapping. To guide others in making optimal-altruistic decisions servant leaders practice persuasion-relying on convincing rather than coercion—nurturing others to dream great dreams (Parris \& Welty Peachey, 2013a, 2013b; Spears, 1998). Persuasive mapping is influencing others based on sound reasoning and mental frameworks through conceptualization (Barbuto \& Wheeler, 2006). Servant leaders build a high-quality relationship by fostering two-way communication and providing evidence-based explanations, logical reasoning, appraisals, inspiration, and/or mentoring. Employees are persuaded to discover voluntarily the right path for them through a mixture of autonomy, direction, empowerment, visioning, and developmental support (Greenleaf, 1977; van Dierendonck, 2011). The use of persuasive mapping can chart issues, lead to conceptualization of greater possibilities, articulate opportunities, encourage others to visualize the future, and offer reasons to serve others, including broader community and society.

Organizational stewardship. Stewardship is committing first and foremost to serving other's needs (Parris \& Welty Peachey, 2013a, 2013b; Spears, 1998). Servant leaders recognize the role of organizations is to create people who will build a better tomorrow, and therefore, they build "people first" organizations that emphasize service (Greenleaf, 1977; Parris \& Welty 
Peachey, 2013b). Organizational stewardship assumes responsibility for the well-being of others and ensures organizational strategies and decisions to make a positive difference. Servant-led organizations act as caretakers and role models working for the common interest of society, developing a community spirit in the workspace, and building a positive legacy (Beck, 2014; Greenleaf, 1977; van Dierendonck, 2011). As Greenleaf (1977: 60) said, “the only way to change a society is to produce people, enough people, who will change it." To servant leaders organizations play a moral role in society to give back and make things better than when they found them. This aligns with family firms' unique organizational culture, where members are motivated intrinsically to act for the collective good (Craig, Dibrell, \& Garrett, 2014).

The behaviors that define servant leadership — altruistic calling, emotional healing, wisdom, persuasive mapping, and organizational stewardship —align strongly with family firms' more frequent presence of ethical values than in nonfamily firms (Blodgett et al., 2011; Duh et al., 2010). A servant-first leadership paradigm for family firms supports Davis, Schoorman, Mayer and Tan's (2000) proposition that employees who identify with the organization and embrace its objectives will be committed to make it succeed over the long term, even at personal sacrifice. Since the majority of global businesses are family firms it is important to emphasize the cross-cultural applicability of servant leadership (Cerit, 2009, 2010; Hamilton \& Bean, 2005; Han et al., 2010; Pekerti \& Sendjaya, 2010). The practice of servant leadership leads to increases in leader and organizational trust (Joseph \& Winston, 2005; Sendjaya \& Perkerti, 2010; Washington, Sutton, \& Field, 2006), organizational citizenship behavior (Ebener \& O'Connell, 2010; Ehrhart, 2004; Hu \& Liden, 2011; Walumbwa, Hartnell, \& Oke, 2010), commitment (Carter \& Baghurst, 2014; Cerit, 2010; Hale \& Fields, 2007; Jamramillo et al., 2009a; 2009b; 
Pekerti \& Sendjaya, 2010), innovation, creativity, and helping behaviors (Hirst, \& Cooper, 2014; Jaramillo et al., 2009b; Neubert et al., 2008; Yoshida, Sandjaya,).

Servant leadership requires social exchanges that are long term, enduring, and ongoing, where individuals maintain consistency and fairness (Brashear, Boles, Bellenger, \& Brooks, 2003). By building a loving and caring community, servant leaders create a multigenerational legacy of serving others first (Parris \& Welty Peachey, 2012). Although there is considerable heterogeneity among family firms, typically they embrace an organizational mindset of longterm orientation (LTO), with priority given to the long-term implications of decisions (Anderson \& Reeb, 2003; Gomez-Mejia, Haynes, Núñez-Nickel, Jacobson, \& Moyano-Fuentes, 2007; Kellermanns, Eddleston, Barnett, \& Pearson, 2008; Lumpkin \& Brigham, 2011). In the context of family firms' desire to continue the business across multiple generations and build a family legacy (Ward 1987, 2004), time considerations are especially important (Anderson \& Reeb, 2003), along with capacity to build enduring relationships (Arregle, Hitt, Sirmon, \& Very, 2007).

Origin of Heterogeneity 3: Though servant leadership as a philosophical frame in our model helps to position heterogeneity from both within and between differences perspectives, our primary focus in this chapter is on the within differences. From a within-family-enterprise perspective, and as part of a configuration approach, there will be differences in how family enterprise leaders (of the family and the business) rank or rate on the five dimensions of the SLQ. On each of the dimensions there will be differences along a continuum, with some dimensions considered innate while others will likely change over the individual's life stage. ${ }^{1}$

\footnotetext{
${ }^{1}$ From a between family and nonfamily enterprise differences perspective, the five dimensions offer valuable clues into philosophical differences between family leaders and their corporate equivalents. Again, using a configuration and continuum approach to diagnose differences, given the motivation and systemic reward systems, there are likely differences between the leadership
} 
Conscious that a debate about fine-grained differences could distract from the purpose of this chapter, we consider that servant leadership provides a valuable philosophical frame to help establish what distinguishes family enterprises. Notable is the inclusion of stewardship as a servant leadership dimension; hence we discuss stewardship below as our next philosophical lens.

\section{Stewardship}

Aligned with the SL positioning of organizational stewardship, we base our inclusion of stewardship as a philosophical dimension in our model on the contention that organizational members gain greater long-term utility from other-focused, prosocial behaviors (Davis et al., 1997; Hernandez, 2012). Pro-organizational and collectivist behaviors are utilized by stewards to gain greater long-term utility than they would from individualistic, self-serving, and economic means. Stewards believe they have a moral obligation to place the organization and its stakeholders above their own interest while ensuring the passing of the firm on to the next generation (Caldwell, Bischoff, \& Karri, 2002; Neubaum, Thomas, Dibrell, \& Craig, 2017). Through role-modeling, instituting policies and procedures, communicating openly and transparently, and fostering organizational identification and intrinsic motivation, stewards create an organizational climate that encourages employees to share and promote the well-being of the collective (Davis et al., 1997; Pearson \& Marler, 2010). Family firms tend to exemplify the tenets of stewardship theory (Corbetta \& Salvato, 2004), and this theory has been used to explain organizational outcomes (Madison, Holt, Kellermanns, \& Ranft, 2015; Shukla, Carney, \& Gedajlovic, 2014). Recently, Neubaum et al. 2017 validated a measure of stewardship providing 
support that the effects of stewardship are stronger in family firms than in nonfamily firms.

There are six interrelated dimensions - intrinsic motivation, organizational identification, use of personal forms of power, collectivism, low power distance, and involvement orientation-that all firms (family and nonfamily) have but, as the emergent evidence indicates, are more effectively embraced by family firms (Davis et al., 1997; Hernandez, 2008, 2012; Vallejo, 2009).

Intrinsic motivation. Stewards create an organizational climate that foster intrinsic motivation, or behavior driven by internal rewards, reinforced through opportunities for personal growth, achievement, affiliation, and self-actualization (Davis et al., 1997; Hernandez, 2008). In a stewardship climate, employees are pushed to work harder for the organization and others because they are fulfilling their higher-order needs-receiving intrinsic benefits through the performance of meaningful and significant work (Hernandez, 2012). Organizational practices of steward-led firms emphasize employee growth and provide intrinsic motivation through selfactualization mechanisms such as praise and support (Deci, 1971; 1972).

Organizational identification. Steward-led organizations can create perceptions of fairness, unity (Greenberg, 1990; Ramamoorthy \& Carroll, 1998), and organizational identification as a function of how they treat their employees (He, Zhu, \& Zheng, 2014; McAllister \& Bigley, 2002). Organizational members who accept an organization's mission, vision, and objectives, as well as define themselves by their involvement within the organization, express organizational identification (Davis et al., 1997). Those who identify with the organization and embrace its objectives desire a relationship with the organization, and are committed to make it succeed over the long term, even at personal sacrifice (Astrachan, Klein, \& Smyrnios, 2002; Davis et al., 2000). A stewardship climate fosters members who identify with the organization, view it as an extension of themselves, and develop a prominent level of 
psychological ownership. Therefore, the members believe they are an intimate part of the business and internalize its success (Hernandez, 2012; Le Breton-Miller \& Miller, 2009; Vallejo, 2009). In alignment, servant-led organizations' employees extend their personal identities and form group-level identities (Parris \& Welty Peachey, 2013b).

Use of personal forms of power. The servant leadership behavior of persuasive mapping is analogous to how stewards do not utilize their positions of authority to lead but rely on their personal informal power gained through relationships built over time (French \& Raven, 1959; Kurland \& Pelled, 2000). Leaders in family firms have extraordinary personal discretion to create organizational values and practices that serve the interest of the company and its employees (De Massis, Kotlar, Chua, \& Chrisman, 2014). The process to become known as a knowledgeable and trusted leader, in accordance with social exchange theory (Blau, 1964), is built upon the leader sharing information, establishing norms of reciprocity, and providing sound rationales for decisions that impact the work done (Heath, 1994; Kurland \& Pelled, 2000). In strong stewardship climates, influencing others through open and lateral exchanges and using forms of personal power are the primary means of building a shared mental model of organizational values and collective responsibility (Kulharni \& Ramamoorthy, 2011).

Collectivism. Organizational values and individual behaviors that embrace "the assumption that groups bind and mutually obligate individuals" (Oyserman, Coon, \& Kemmelmeier, 2002, p. 5) are exemplified in stewardship climates (Early \& Erez, 1997). Stewards direct behavior toward accomplishing the collective good through creating an environment where individuals share responsibility for the accomplishment of positive outcomes (Hernandez, 2012). In collectivist cultures individuals form a group identity, a sense of belonging, and a belief that their individual contributions lead to the firm's success or failure. 
Low power distance. In organizations that identify with high stewardship virtues, the leader views their leadership as incomplete without a group of equals to build upon their talents. Greenleaf (1977) called these leaders primus inter pares-first among equals. Alternatively, in high-power-distance organizational climates lower-rank members are dependent on permission and direction from those with higher power, status, and special privileges. Through fostering egalitarian interactions, discouraging inequalities, and treating others equally, organizational members without formal titles or authority accept unequal distribution of power across organizational levels (Dorfman \& Howell, 1988). Inclusive action and collective responsibilities are outcomes of a strong stewardship climate (Hernandez, 2012).

Involvement orientation. An inclusive environment that provides employees autonomy and involvement in decision-making processes results in higher engagement benefiting the organization and the employees (Butts, Vandenberg, DeJoy, Schaffer, \& Wilson, 2009; Riordan, Vandenberg, \& Richardson, 2005). Involvement-oriented management environments, consistent with a stewardship climate and servant leadership theory, enable members to reach their potential, provide increasing responsibilities and challenges, and support the collective achievement of organizational objectives (Hernandez, 2012). Self-management work climates offer employees the chance to expand their knowledge, innovate, solve organizational problems, and provide intrinsic rewards for achieving organizational outcomes.

Led by steward leaders, family businesses are more likely to be concerned and supportive, and to provide for employees. In comparison to nonfamily firms, this additional level of care in family firms for organizational members has resulted conceptually or empirically in: greater employee trust, commitment to the organization, and prosocial behaviors (Pearson \& Marler, 2010); higher levels of intrinsic motivation (Bammens, Notelaers, \& Van Gils, 2015), 
organizational identification (Schröder, Schmitt-Rodermund, \& Arnaud, 2011; Vallejo, 2008), and involvement orientation (Bammens et al., 2015); as well as increased use of personal forms of power (Marques, Presas, \& Simon, 2014), lower power distance (Sharma \& Manikutty, 2005), and collective action (Eddleston \& Kellermanns, 2007).

Origin of Heterogeneity 4: Stewardship as introduced conceptually by Davis et al. (1997) and validated empirically recently by Neubaum et al. (2017) canvasses both individual (psychological) and organizational (situational) perspectives. Again, as we did with SL, taking a configuration and continuum approach, it is possible to establish within (an individual family business; an individual family) differences along the six stewardship dimensions, which adds considerably to the understanding of family firm heterogeneity. Being careful not to be drawn into a detailed discussion that could take us along a path that detracts from the purpose of this chapter, we consider that family firms that embrace stewardship (and servant leadership) build trust, our third foundation philosophy.

\section{Trust}

Trust is embedded in economic transactions and social relationships (Fish, Parris, \& Troilo, 2017; Granovetter, 1985) and can be understood by exploring its causes, nature, and effects (Parris, Dapko, Arnold, \& Arnold, 2016). It is defined as "the subjective probability with which an agent [trustor] assesses that another agent or group of agents [trustees] will perform a particular beneficial action" (James 2002, p. 292). Trust as social capital is critical for family firms to apply the frameworks of servant leadership and stewardship climate. For leaders in family firms it is important to develop a deeper understanding of trust to fulfill their members' need for a deeper purpose and meaning, and create an organizational culture that harnesses the power of people working together (i.e., social capital) to create positive change. 
The most widely cited models of trust were developed by Mayer et al. (1995), focusing on the interpersonal nature of trust, and extended into corporate trust and stakeholder trust by Schoorman et al. (2007). Trust implies vulnerability, as highlighted in their model that proposed perceptions of trustworthiness contribute to a person's willingness to take risks with another party. Trusting an individual or an organization requires two components: (1) belief in the trustworthiness of others, and (2) one's specific preferences with regard to risk aversion, reciprocity, and altruism (Ashraf, Bohnet, \& Piankov, 2006; Cox, 2004; Karlan, 2005; Sapienza, Toldra-Simats, \& Zingales, 2013). The willingness to be vulnerable can be predicted: if the perceived potential benefits outweigh the perceived potential costs, then the individual will be more willing to take a risk in a given relationship.

An individual or organization is perceived as trustworthy based on favorable evaluations of four dimensions: ability (competence and expertise that enables someone to influence a domain); benevolence (the extent to which a trustee is believed to want to do good to the trustor); integrity (the trustor's perception that the trustee adheres to a set of moral principles that the trustor finds satisfactory) (Mayer et al.,1995; Schoorman et al., 2007); consistency (the expectation that the trustee will adhere to the same principles).

A trusting relationship is highly unlikely when an individual has a low propensity to trust and perceives another individual as lacking ability, benevolence, integrity, or consistency. To create a sense of trustworthiness and accountability, organizational members, servant leaders, and stewards can build trust in an organization based on perceived organizational transparency through sharing information, creating learning opportunities, and communicating openly (Parris et al., 2016). 
Origin of Heterogeneity 5: To demonstrate how the dimensions of trust potentially configure differently, and how each configuration impacts the perception versus reality of trustworthiness, consider the following profile: IaBc. In this configuration, an individual would be considered high on Integrity and Benevolence (thus the capital letters) but have a shortfall related to ability and consistency (lowercase letters). Interpreting this, it could be that the individual is of morally high standing and means well but is not capable and does not deliver at expected levels. So, without detailing and examining potential different configurations, it should be evident how the four dimensions of trust help to understand and appreciate heterogeneity in family firms. While positioned here for our purposes in individual differences terms, the fundamental principles apply at the organizational level of analyses so, again, between and within differences can be highlighted.

\section{Where Heterogeneity is Observable: Firm-Level and Individual-Level Frameworks}

The third section of our model introduces two related frameworks_-organizational-level (AGES; Figure 3) and individual-level (SAGE; Figure 3) - that capture the preceding mindset (i.e., paradigm and logics) and philosophies (i.e., servant leadership, stewardship, trust) considerations. The motivation behind creating these frameworks is to introduce into the lexicon theory-driven, evidence-based tools that efficiently and effectively consider where the within and between differences manifest. Understanding these, we argue, will facilitate the development of requisite skillsets to improve family enterprise functioning. 
The AGES framework is built around the areas in which unique features of familycontrolled businesses are evident: Architecture, Governance, Entrepreneurship, and Stewardship. In broad terms: ${ }^{2}$

Architecture includes the underlying observable structures and systems, as well as the origins and outcome differences related to these, that are in place to deliver firm strategy (i.e., the how). So, pivotal in the AGES framework, architecture is in place to furnish governance, entrepreneurship, and stewardship (or the 'G,' 'E,' and 'S' of the framework). The architectures dictate both organizational activities and the authority and autonomy of those designated to undertake the activities. Architectures are (1) inherently different in all family firms, (2) will manifest in either functional, multidimensional, or matrix formats, (3) which will determine the managerial control systems, and (4) the functional systems in place, including performance, human resources and marketing. In short, these architectures typically entail (1) flatter structures that enable (2) faster decision-making and (3) less sophisticated systems that are complemented by (4) clan-based controls.

Governance canvasses both business and family governance structures and some of the processes (i.e., the who decides whether and when). Governance provides direction, control, and accountability for an enterprise, to promote unity and commitment of ownership. For family enterprises the mixture of business, family, and ownership concerns makes governance more challenging than in nonfamily businesses, as this overlap often leads to a greater divergence of views on how the firm should be run, the direction it should take, and the steps needed to achieve

\footnotetext{
${ }^{2}$ For more detail on AGES and SAGE frameworks, see Craig, J. B. and Moores, K. (2017) Leading A Family Business: Best Practice for Long-term Stewardship. Praegar Publishing.
} 
its goals. For the family, governance is a means to protect its wealth and preserve the family legacy, for generations to come.

In general, governance systems are used to direct and control an organization for and on behalf of the owners. They are built upon an interlocking framework of rules, relationships, structures, systems, and processes within and by which organizational authority is exercised and controlled. Understanding the unique governance dynamics of family business requires distinguishing between business governance and family governance, and therein lies the fundamental 'between' difference. Still, when discussing heterogeneity of family enterprises, the ‘within' differences are similarly notable. Simply put, business and family evolution demands evolving governance, and this denotes considerable life-stage influenced heterogeneity.

Finally, regarding the AGES dimension, the governance of family business is arguably more difficult than that in firms with more widely dispersed owners, as owners increasingly have different expectations of the business and, at the same time, also have limited opportunities to either influence others or liquidate their ownership relative to public company shareholders.

Entrepreneurship covers strategy and leadership (i.e., the what). To understand and explain entrepreneurship in family versus nonfamily businesses, the concept of entrepreneurial orientation (EO) is useful. The original measurement of the EO construct, which is based on the processes, practices, and decision-making approaches of firms that act entrepreneurially, suggested three main dimensions: innovativeness (a firm's tendency to engage in and support new ideas, novelty, experimentation, and creative processes that result in new products, services, or technological processes); proactivity (the propensity to compete aggressively and proactively with industry rivals); and risk-taking (the tendency of a firm's top management to take risks related to investment decisions and strategic choices in the face of uncertainty). Each of these 
three dimensions varies independently of the others, which suggests heterogeneity, as an entrepreneurial firm's levels of the three dimensions will differ, and their relative positions will likely change over time.

Stewardship is arguably the key differentiator and looks at both individual- and familybusiness-level processes (i.e., the why) (see Figure 3), and has been discussed in the previous section related to philosophies.

\section{FIGURE 3 HERE}

\section{SAGE}

The SAGE framework, which is derived from the AGES framework, captures the four roles that a family businesses leader needs to master concurrently to lead both the business and the family capably. Specifically, he or she needs to be a Steward, an Architect, a Governor and an Entrepreneur.

\section{Outcomes of Heterogeneity: Skill-sets Required to Function Effectively in Heterogeneous World of Family Business}

The final part of our model considers the skill-sets emanating from the antecedent elements discussed. Fundamentally, our argument is that an appreciation of the diverse and evolving sub-parts of the model will contribute to those involved, whether in a business or a family role, being better prepared to lead, to govern, to innovate, and to adapt. To capture the importance of having a way to understand the underlying heterogeneity in family enterprises, we divide this part into family and business skill-sets. 
Family Skill-sets. As family enterprises introduce family governance initiatives to improve communication and education, opportunities to contribute in non-operational roles are developed. Forums and programs such as family assembly, family council, family office, and the associated guiding documents (e.g., family charter or constitution) require leadership and resourcing by committed and prepared family members. Our thesis is that the 3 -circle paradigm, dual-logics mindset, philosophies anchored in servant leadership, stewardship and trust, and the firm- and individual-level frameworks we have introduced in the first three parts of the model are integral to such preparation.

Business Skill-sets. As family enterprises introduce business governance initiatives to provide independence and accountability and attract highest-caliber family and nonfamily executives and directors, an understanding of what distinguishes family enterprises from nonfamily enterprises and an individual family enterprise from other family enterprises is required to discharge responsibilities and contribute optimally. Given the vastness of the field and the considerable heterogeneity discussed above, it is important, even mandatory, that those recruited to business roles are well-versed in what (1) distinguishes family enterprises, and (2) what is distinctive about a specific family business. To illustrate, consider an independent director or nonfamily professional manager who has been approached to join a family enterprise board or executive team. Though likely accomplished in the corporate nonfamily domain, the targeted director or manager would benefit from reviewing the idiosyncratic family enterprise context using the core F-O-M paradigm and the dual-logics mindset, the philosophies linked to servant leadership, stewardship, and trust and the AGES and SAGE frameworks. Similarly, a married-in or even next-generation family member would benefit by reviewing the antecedents to understand what is distinctive about their family enterprise. 


\section{Discussion}

To gain a deeper understanding of how family enterprises are all the same but different we identified five origins of heterogeneity: two primary antecedents - the presence of family (i.e., FOM Venn diagram) and their pursuit of dual logics in decision-making - that inform three philosophies: servant leadership, stewardship, and trust. These origins of heterogeneity shape the structure, processes, and systems of family firms and are observable at the organizational (AGES) and individual levels (SAGE). The AGES framework provides insight into how a family firm is controlled; the SAGE framework captures the four roles a family business leader needs to lead. The outcomes of a family firm's mindsets, philosophies, and frameworks require family firm leaders to have both family and business skill-sets to function effectively in the heterogenous world of family business. A conceptual meta-model of family enterprise heterogeneity representing these elements (Figure 1) can be used as guide for family firms to identify the perception versus reality of their heterogeneity, and then help them to develop strategies to maintain organizational culture or evaluate organizational change.

In a family firm, any group or individuals (i.e., stakeholders) will most likely form perceptions of the firm's heterogeneity during some communication interaction with the firm. A communication interaction can be either stakeholder-initiated or firm-initiated, and is a communication event where information is shared between the firm and stakeholder. Each communication interaction has the potential to change stakeholder perceptions of the family firm's heterogeneity. The reality of heterogeneity behavior relates to actual behaviors exhibited by organizational members, and will have strong impact on stakeholder perceptions; but reality and perception may not match, due to potential intervening variables. Each variable in the conceptual meta-model of family enterprise heterogeneity (Figure 1) can be evaluated along a 
spectrum utilizing perception and reality behavior grid, ${ }^{3}$ as shown in Figure 5. For example, a family firm could evaluate one of the core mindsets, such as their dual logics. The reality of dual-logics behavior and its perception can both be high, as shown in Quadrant II in Figure 4. In this case, if having both economic and non-economic imperatives is strategically important, the family firm would need to maintain status quo; however, if any factor is low as represented in Quadrant I, III, and IV, the firm would then pursue something different.

\section{INSERT FIGURE 4 HERE}

\section{Implications for Practice}

The inherent heterogeneity of family firms challenges their leaders to understand how their organization is unique or similar. We provide a conceptual model of family firm heterogeneity to help family firm leaders develop a deeper understanding of their firm's mindsets, philosophies, frameworks, and skill-sets to make informed strategic decisions that further support the organizational culture or evaluate organizational change. As each antecedent informs the others, it is critical family firms leaders acknowledge and evaluate the intended and unintended consequences of increasing or decreasing any of the factors, as well as explore whether a factor should be strengthened or deemphasized. For instance, a family firm that is high in both perception and reality of practicing servant leadership may be high on four of the six dimensions of servant leadership, and decide to strengthen one or two dimensions by refining the organizational (AGES) and individual (SAGE) frameworks.

\section{Future Research}

\footnotetext{
${ }^{3}$ For more detail on the perception and reality behavior grid, see Parris et al. (2016) Exploring transparency: A new framework for responsible business management. Organizational Dynamics.
} 
Our conceptual model provides a template for scholars to advance the study of family firms and test application of the model empirically. Of particular benefit would be (1) experimental-design research that furthers the understanding of the mindsets that drive decisionmaking, (2) studies that examine relationships among servant leadership, stewardship, and trust, which could lead to a robust meta-philosophical diagnostic to better inform both family and nonfamily fields, and (3) longitudinal research that includes the dimensions of our model and which captures both economic and non-economic output measures.

\section{Conclusion}

Mindsets of those involved in family enterprises inform both the three independent and interdependent family-owner-manager systems and the dual economic and non-economic logics. Building on this underpinning of paradigmatic and logics, servant leadership, stewardship theory, and trust provide rich philosophical foundations that inform frameworks at both organizational (AGES) and individual (SAGE) levels, which isolate the observable differences both between family firms and nonfamily firms and within our class of firms. Understanding these relationships provides a foundation to the development of skill-sets needed to manage successfully the heterogeneity confronted by family business leaders. 


\section{References}

Aldrich, H. E., \& Cliff, J. E. (2003). The pervasive effects of family on entrepreneurship: Toward a family embeddedness perspective. Journal of Business Venturing, 18(5), 573596.

Anderson, R. C., \& Reeb, D. M. (2003). Founding-family ownership and firm performance: evidence from the S\&P 500. The Journal of Finance, 58(3), 1301-1328.

Arregle, J. L., Hitt, M. A., Sirmon, D. G., \& Very, P. (2007). The development of organizational social capital: Attributes of family firms. Journal of Management Studies, 44(1), 73-95.

Ashraf, N., Bohnet, I., \& Piankov, N. (2006). Decomposing trust and trustworthiness. Experimental Economics, 9(3), 193-208.

Astrachan, J. H., Klein, S. B., \& Smyrnios, K. X. (2002). The F-PEC scale of family influence: A proposal for solving the family business definition problem. Family Business Review, $15(1), 45-58$.

Bammens, Y., Notelaers, G., \& Van Gils, A. (2015). Implications of family business employment for employees' innovative work involvement. Family Business Review, 28(2), 123-144. 
Barbuto, J. E., \& Wheeler, D. W. (2002). Becoming a servant leader: Do you have what it takes? NebGuide G02-1481-A. Lincoln: University of Nebraska, Nebraska Cooperative Extension.

Barbuto, J. E., \& Wheeler, D. W. (2006). Scale development and construct clarification of servant leadership. Group \& Organization Management, 31(3), 300-326.

Basco, R., \& Pérez Rodríguez, M. J. (2009). Studying the family enterprise holistically: Evidence for integrated family and business systems. Family Business Review, 22(1), 8295.

Bass, B. M. (2000). The future of leadership in learning organizations. Journal of Leadership \& Organizational Studies, 7(3), 18-40.

Beck, C. D. (2014). Antecedents of servant leadership: A mixed methods study. Journal of Leadership \& Organizational Studies, 21(3), 299-314.

Berrone, P., Cruz, C., \& Gómez-Mejía, L. R. (2012). Socioemotional wealth in family firms: Theoretical dimensions, assessment approaches, and agenda for future research. Family Business Research, 25(3), 258-279.

Bierly, P. E., Kessler, E. H., \& Christensen, E. W. (2000). Organizational learning, knowledge and wisdom. Journal of Organizational Change Management, 13(6), 595-618.

Bingham, J. B., Dyer Jr, W. G., Smith, I., \& Adams, G. L. (2011). A stakeholder identity orientation approach to corporate social performance in family firms. Journal of Business Ethics, 99(4), 565-585. 
Black, G.L. (2010). Correlational analysis of servant leadership and school climate. Catholic Education: A Journal of Inquiry \& Practice, 13(4), 437-466.

Blau, P. (1964). Exchange and Power in Social Life. New York, NY: Wiley.

Blodgett, M. S., Dumas, C., \& Zanzi, A. (2011). Emerging trends in global ethics: A comparative study of US and international family business values. Journal of Business Ethics, 99(1), 29-38.

Born, M., (1956). Experiment and Theory in Physics. New York: Dover.

Brashear, T. G., Boles, J. S., Bellenger, D. N., \& Brooks, C. M. (2003). An empirical test of trust-building processes and outcomes in sales manager-salesperson relationships. Journal of the Academy of Marketing Science, 31(2), 189-200.

Butts, M. M., Vandenberg, R. J., DeJoy, D. M., Schaffer, B. S., \& Wilson, M. G. (2009). Individual reactions to high involvement work processes: Investigating the role of empowerment and perceived organizational support. Journal of Occupational Health Psychology, 14(2), 122-136.

Caldwell, C., Bischoff, S. J., \& Karri, R. (2002). The four umpires: A paradigm for ethical leadership. Journal of Business Ethics, 36(1-2), 153-163.

Carter, D., \& Baghurst, T. (2014). The influence of servant leadership on restaurant employee engagement. Journal of Business Ethics, 124(3), 453-464.

Cerit, Y. (2009). The effects of servant leadership behaviors of school principals on teachers' job satisfaction. Educational Management Administration \& Leadership, 37(5), 600-623. 
Cerit, Y. (2010). The effects of servant leadership on teachers' organizational commitment in primary schools in Turkey. International Journal of Leadership in Education, 13(3), 301317.

Chrisman, J. J., \& Patel, P. C. (2012). Variations in R\&D investments of family and nonfamily firms: Behavioral agency and myopic loss aversion perspectives. Academy of Management Journal, 55(4), 976-997.

Christensen, C. M. (2006). The ongoing process of building a theory of disruption. Journal of Product Innovation Management, 23(1), 39-55.

Chua, J. H., Chrisman, J. J., \& De Massis A. (2015). A closer look at socioemotional wealth: Its flows, stocks, and prospects for moving forward. Entrepreneurship Theory and Practice, 39(2), 173-182.

Chua, J. H., Chrisman, J. J., Steier, L. P., \& Rau, S. B. (2012). Sources of heterogeneity in family firms: An introduction. Entrepreneurship Theory and Practice, 36(6), 1103-1113.

Corbetta, G., \& Salvato, C. (2004). Self-Serving or Self-Actualizing? Models of Man and Agency Costs in Different Types of Family Firms: A Commentary on "Comparing the Agency Costs of Family and Non-family Firms: Conceptual Issues and Exploratory Evidence". Entrepreneurship Theory and Practice, 28(4), 355-362.

Cox, J. (2004). How to identify trust and reciprocity. Games and Economic Behavior, 46(2), 260-281. 
Craig, J. B., Dibrell, C., \& Garrett, R. (2014). Examining relationships among family influence, family culture, flexible planning systems, innovativeness and firm performance. Journal of Family Business Strategy, 5(3), 229-238.

Cyert, R. M., \& March, J. G. (1963). A Behavioral Theory of the Firm, Prentice Hall, New Jersey.

Davis, J. H., Schoorman, F. D., \& Donaldson, L. (1997). Toward a stewardship theory of management, Academy of Management Review, 22(1), 20-47.

Davis, J. H., Schoorman, F. D., Mayer, R. C., \& Tan, H. H. (2000). The trusted general manager and business unit performance: Empirical evidence of a competitive advantage. Strategic Management Journal, 21(5), 563-576.

Deci, E. L. (1971). Effects of externally mediated rewards on intrinsic motivation. Journal of Personality and Social Psychology, 18(1), 105-115.

Deci, E. L. (1972). Intrinsic motivation, extrinsic reinforcement, and inequity. Journal of Personality and Social Psychology, 22(1), 113-120.

Dekker, J. C., Lybaert, N., Steijers, T., Depaire, B., \& Mercken, R. (2012). Family Firm Types based on the Professionalization Construct: Exploratory Research. Family Business Review, 26(1), 81-99.

De Massis, A., Kotlar, J., Chua, J. H., \& Chrisman, J. J. (2014). Ability and willingness as sufficiency conditions for family-oriented particularistic behavior: Implications for theory and empirical studies. Journal of Small Business Management, 52(2), 344-364. 
DiMaggio, P. J., \& Powell, W. W. (1983). The Iron Cage revisited: institutional isomorphism and collective rationality in organizational fields. American Sociological Review, 48(2), $147-160$.

Dorfman, P. W., \& Howell, J. P. (1988). Dimensions of national culture and effective leadership in patterns. Advances in International Comparative Management, 3, 127-150.

Duh, M., Belak, J., \& Milfelner, B. (2010). Core values, culture and ethical climate as constitutional elements of ethical behaviour: Exploring differences between family and nonfamily enterprises. Journal of Business Ethics, 97(3), 473-489.

Early, P. C., \& Erez, M. (1997). New Perspectives on International Industrial/Organizational Psychology. San Francisco, CA: Jossey-Bass.

Ebener, D. R., \& O’Connell, D. J. (2010). How might servant leadership work? Nonprofit Management and Leadership, 20(3), 315-335.

Eddleston, K. A., Kellermanns, F. W., \& Zellweger, T. M. (2012). Exploring the entrepreneurial behavior of family firms: Does the stewardship perspective explain differences? Entrepreneurship Theory and Practice, 36(2), 347-367.

Ehrhart, M. G. (2004). Leadership and procedural justice climate as antecedents of unit-level organizational citizenship behavior. Personnel Psychology, 57(1), 61-94.

Fish, J., Parris, D., \& Troilo, M. (2017). Compound voids and unproductive entrepreneurship: The rise of the "English Fever" in China. Journal of Economic Issues, 51(1), 163-180. 
French, J. R. P., \& Raven, B. (1959). The bases of social power. In D. Cartwright (Ed.), Studies in social power (pp. 150-167). Ann Arbor: University of Michigan Institute for Social Research.

Gómez-Mejía, L. R., Haynes, K. T., Núñez-Nickel, M., Jacobson, K. J., \& Moyano-Fuentes, J. (2007). Socioemotional wealth and business risks in family-controlled firms: Evidence from Spanish olive oil mills. Administrative Science Quarterly, 52(1), 106-137.

Graham, J. (1991). Servant-leadership in organizations: Inspirational and moral. Leadership Quarterly, 2(2), 105-119.

Granovetter, M. (1985). Economic action and social structure: A theory of embeddedness. American Journal of Sociology, 91(3), 481-510.

Greenberg, J. (1990). Organizational justice: Yesterday, today, and tomorrow. Journal of Management, 16(2), 399-432.

Greenleaf, R. K. (1970). The Servant as Leader. Indianapolis: The Robert K. Greenleaf Center.

Greenleaf, R. K. (1972a). The Institution as Servant. Indianapolis: The Robert K. Greenleaf Center.

Greenleaf, R. K. (1972b). Trustees as Servants. Indianapolis: The Robert K. Greenleaf Center.

Greenleaf, R. K. (1977). Servant Leadership: A Journey into the Nature of Legitimate Power and Greatness. New York: Paulist Press.

Hale, J. R., \& Fields, D. L. (2007). Exploring servant leadership across cultures: A study of followers in Ghana and the USA. Leadership, 3(4), 397-417. 
Hamilton, F., \& Bean, C. J. (2005). The importance of context, beliefs and values in leadership development. Business Ethics: A European Review, 14(4), 336-347.

Han, Y., Kakabadse, N. K., \& Kakabadse, A. (2010). Servant leadership in the People's Republic of China: A case study of the public sector. Journal of Management Development, 29(3), $265-281$.

He, H., Zhu, W., \& Zheng, X. (2014). Procedural justice and employee engagement: Roles of organizational identification and moral identity centrality. Journal of Business Ethics, 122(4), 681-695.

Heath, R. L. (1994). Management of Corporate Communication: From Interpersonal Contacts to External Affairs. Hillsdale, NJ: Lawrence Erlbaum.

Hernandez, M. (2008). Promoting stewardship behavior in organizations. Journal of Business Ethics, 80(1), 121-128.

Hernandez, M. (2012). Toward an understanding of the psychology of stewardship. Academy of Management Review, 37(2), 172-193.

Hu, J., \& Liden, R. C. (2011). Antecedents of team potency and team effectiveness: An examination of goal and process clarity and servant leadership. Journal of Applied Psychology, 96(4), 851-862.

James, H. (2002). The trust paradox: A survey of economic inquiries into the nature of trust and trustworthiness. Journal of Economic Behaviour \& Organization, 47(3), 291-307. 
Jaramillo, F., Grisaffe, D. B., Chonko, L. B., \& Roberts, J. A. (2009a). Examining the impact of servant leadership on sales force performance. Journal of Personal Selling \& Sales Management, 29(3), 257-275.

Jaramillo, F., Grisaffe, D. B., Chonko, L. B., \& Roberts, J. A. (2009b). Examining the impact of servant leadership on salesperson's turnover intention. Journal of Personal Selling \& Sales Management, 29(4), 351-365.

Joseph, E. E., \& Winston, B. E. (2005). A correlation of servant leadership, leader trust, and organizational trust. Leadership \& Organization Development Journal, 26(1), 6-22.

Kant, I. (1978). Anthropology from a Pragmatic Point of View (V. L. Dowdell, Trans.). Carbondale: Southern Illinois University Press. (Original work published 1798).

Karlan, D. (2005). Using experimental economics to measure social capital and predict financial decisions. American Economic Review, 95(5), 1688-1699.

Kellermanns, F. W., Eddleston, K. A., Barnett, T., \& Pearson, A. (2008). An exploratory study of family member characteristics and involvement: Effects on entrepreneurial behavior in the family firm. Family Business Review, 21(1), 1-14.

Kets de Vries, M. F. R. (1993). “The dynamics of family-controlled firms”, Organizational Dynamics, 21(3), 59-71.

Kuhn, T. S. (1970). The Structure of Scientific Revolutions. Chicago: Chicago University Press.

Kulharni, S., \& Ramamoorthy, N. (2011). Leader-member exchange, subordinate stewardship, and hierarchical governance. International Journal of Human Resource Management, 22(13), 2770-2793. 
Kurland, N. B., \& Pelled, L. H. (2000). Passing the word: Toward a model of gossip and power in the workplace. Academy of Management Review, 25(2), 428-439.

Lanctot, J. D., \& Irving, J. A. (2010). Character and leadership: Situating servant leadership in a proposed virtues framework. International Journal of Leadership Studies, 6(1), 28-50.

Laub, J. A. (1999). Assessing the servant organization; Development of the Organizational Leadership Assessment (OLA) model. Dissertation Abstracts International, 60(2), 308A (UMI No. 9921922).

Le Breton-Miller, I., \& Miller, D. (2009). Agency vs. stewardship in public family firms: A social embeddedness reconciliation. Entrepreneurship Theory and Practice, 33(6), 11691191.

Liden, R. C., Wayne, S. J., Zhao, H., \& Henderson, D. (2008). Servant leadership: Development of a multidimensional measure and multi-level assessment. Leadership Quarterly, 19(2), $161-177$.

Lumpkin, G. T., \& Brigham, K. H. (2011). Long-term orientation and intertemporal choice in family firms. Entrepreneurship Theory and Practice, 35(6), 1149-1169.

Madison, K., Holt, D. T., Kellermanns, F. W. \& Ranft, A. (2015). Viewing family firm behavior and governance through the lens of agency and stewardship theories, Family Business Review, 29(1), 65-93.

Marques, P., Presas, P., \& Simon, A. (2014). The heterogeneity of family firms in CSR engagement: The role of values. Family Business Review, 27(3), 206-227. 
Martin, G., \& Gomez-Mejia, L. R. (2016). The relationship between socioemotional and financial wealth Re-visiting family firm decision making. Management Research, 14(3), 215-233.

Mayer, R. C., Davis, J.H., \& Schoorman, F. D. (1995). An integrative model of organizational trust. Academy of Management Review, 20(3), 709-734.

McAllister, D. J., \& Bigley, G. A. (2002). Work context and the definition of self: How organizational care influences organization-based self-esteem. Academy of Management Journal, 45(5), 894-904.

Miller D., \& Le Breton-Miller I. (2014). Deconstructing socioemotional wealth. Entrepreneurship Theory and Practice, 38(4), 713-720.

Miller, D., \& Le Breton-Miller, I. (2005). Management insights from great and struggling family businesses. Long Range Planning, 38(6), 517-530.

Moores, K. (2009). Paradigms and theory building in the domain of business families. Family Business Review, 22(2), 167-180.

Muntean, S. C., Phan, P. H., \& Butler, J. E. (2008). Analyzing the dearth in family enterprise research. Theoretical Developments and Future Research in Family Business, 3-26.

Neubaum, D. O., Thomas, C. H., Dibrell, C., \& Craig, J. B. (2017). Stewardship climate scale: An assessment of reliability and validity. Family Business Review, 30(1), 37-60.

Neubert, M. J., Kacmar, K. M., Carlson, D. S., Chonko, L. B., \& Roberts, J. A. (2008). Regulatory focus as a mediator of the influence of initiating structure and servant leadership on employee behavior. Journal of Applied Psychology, 93(6), 1220-1233. 
Nieli, R. (1986). Spheres of intimacy and the Adam Smith Problem. Journal of the History of Ideas, 47(4), 611-624.

Oyserman, D., Coon, H. M., \& Kemmelmeier, M. (2002). Rethinking individualism and collectivism: Evaluation of theoretical assumptions and meta-analyses. Psychological Bulletin, 128(1), 3-72.

Pache, A. C., \& Santos, F. (2013). Inside the hybrid organization: Selective coupling as a response to competing institutional logics. Academy of Management Journal, 56(4), 972 1001.

Parolini, J., Patterson, K., \& Winston, B. (2009). Distinguishing between transformational and servant leadership. Leadership \& Organizational Development Journal, 30(3), 274-29.

Parris, D., Dapko, J., Arnold, W., \& Arnold, D. (2016). Exploring transparency: A new framework for responsible business management. Management Decision, 54(1), 222247.

Parris, D., \& Welty Peachey, J. (2013a). A systematic literature review of servant leadership theory in organizational contexts. Journal of Business Ethics, 113(3), 377-393.

Parris, D., \& Welty Peachey, J. (2013b). Encouraging servant leadership: A qualitative study of how a cause-related sporting event inspires participants. Leadership, 9(4), 486-512.

Parris, D. L., \& Welty Peachey, J. (2012). Building a legacy of volunteers through servant leadership: A cause-related sporting event. Nonprofit Management and Leadership, 23(2), 259-276. 
Pearson, A. W., \& Marler, L. E. (2010). A leadership perspective of reciprocal stewardship in family firms. Entrepreneurship Theory and Practice, 34(6), 1117-1124.

Pekerti, A. A., \& Sendjaya, S. (2010). Exploring servant leadership across cultures: Comparative study in Australia and Indonesia. The International Journal of Human Resource Management, 21(5), 754-780.

Plato. (1945). The Republic of Plato (F. M. Cornford, Trans.). New York: Oxford University Press.

Putnam, R. D. (1995) Bowling alone: America's declining social capital. Journal of Democracy, $6(1), 65-78$.

Ramamoorthy, N., \& Carroll, S. J. (1998). Individualism/collectivism orientations and reactions toward alternative human resource management practices. Human Relations, 51(5), 571588.

Riordan, C. M., Vandenberg, R. J., \& Richardson, H. A. (2005). Employee involvement climate and organizational effectiveness. Human Resource Management, 44(4), 471-488.

Russell, R. (2001). The role of values in servant leadership. Leadership \& Organization Development Journal, 22(2), 76-83.

Sapienza, P., Toldra-Simats, A., \& Zingales, L. (2013). Understanding trust. Economic Journal, 123(573), 1313-1332.

Schoorman, F. D., Mayer, R. C., \& Davis, J. H. (2007). An integrative model of organizational trust: past, present, and future. Academy of Management Review, 32(2), 344-354. 
Schröder, E., Schmitt-Rodermund, E., \& Arnaud, N. (2011). Career choice intentions of adolescents with a family business background. Family Business Review, 24, 305-321.

Sendjaya, S., \& Pekerti, A. (2010). Servant leadership as antecedent of trust in organizations. Leadership \& Organization Development Journal, 31(7), 643-663.

Sendjaya, S., \& Sarros, J. (2002). Servant leadership: Its origin, development, and application in organizations. Journal of Leadership and Organizational Studies, 9(2), 57-64.

Sharma, P., Chrisman, J. J., \& Chua, J. H. (1997). Strategic management of the family business: Past research and future challenges. Family Business Review, 10(1), 1-35.

Sharma, P., \& Manikutty, S. (2005). Strategic divestments in family firms: Role of family structure and community culture. Entrepreneurship Theory and Practice, 29(3), 293-311.

Sharma, P., \& Nordqvist, M. (2008). A classification scheme for family firms: From family values to effective governance to firm performance. In Tàpies, J., \& Ward, J. L. (Eds.), Family Values and Value Creation: The Fostering of Enduring Values within Family Owned Businesses, 71-101. United Kingdom: Palgrave Macmillan.

Shulka, P. P., Carney, M., \& Gedajlovic, E. (2014). Economic theories of family firms. In L. Melin, M. Nordqvist \& P. Sharma (Eds.), The Sage handbook of family business (pp. 100-118). London, England: Sage.

Smith, A. (1976). The Theory of the Moral Sentiments, D. Raphael, A.L. Macfie (eds.). Indianapolis, IA: Liberty Press.

Smith, A. (1994). An Inquiry into the Nature and Causes of the Wealth of Nations, E. Cannan (ed.). New York: Modern Library. 
Spears, L. (1995). Introduction: Servant-leadership and the Greenleaf legacy. In L. Spears (Ed.), Reflections of leadership: How Robert K. Greenleaf's theory of servant leadership influenced today's top management thinkers (pp. 1-16). New York: Wiley.

Spears, L. (1998). Insights on Leadership: Service, Stewardship, Spirit, and Servant Leadership. New York: Wiley.

Stewart, A., \& Hitt, M. A., (2012). Why Can’t a Family Business be more like a Nonfamily Business? Modes of Professionalization in Family Firms. Family Business Review, 25(1), 58-86.

Vallejo, M. C. (2008). Is the culture of family firms really different? A value-based model for its survival through generations. Journal of Business Ethics, 81(2), 261-279.

Vallejo, M. C. (2009). The effects of commitment of nonfamily employees of family firms from the perspective of stewardship theory. Journal of Business Ethics, 87(3), 379-390.

Vallejo, M. C., \& Langa, D. (2010). Effects of family socialization in the organizational commitment of the family firms from the moral economy perspective. Journal of Business Ethics, 96(1), 49-62.

van Dierendonck, D. (2011). Servant leadership: A review and synthesis. Journal of Management, 37(4), 1228-1261.

van Dierendonck, D., \& Nuijten, I. (2011). The servant leadership survey: Development and validation of a multidimensional measure. Journal of Business and Psychology, 26(3), 249-267. 
Walumbwa, F. O., Hartnell, C. A., \& Oke, A. (2010). Servant leadership, procedural justice climate, service climate, employee attitudes, and organizational citizenship behavior: A cross-level investigation. Journal of Applied Psychology, 95(3), 517-529.

Ward, J. L. (1987). Keeping the Family Business Healthy: How to Plan for Continuity Growth, Profitability and Family Leadership. San Francisco, CA: Jossey-Bass.

Ward, J. L. (2004). Perpetuating the Family Business. 50 Lessons Learned from Long-Lasting, Successful Families in Business. New York: Palgrave Macmillan.

Washington, R. R., Sutton, C. D., \& Feild, H. S. (2006). Individual differences in servant leadership: The roles of values and personality. Leadership \& Organization Development Journal, 27(8), 700-716.

Whetstone, J. (2002). Personalism and moral leadership: the servant leader with a transforming vision. Leadership and Organizational Development Journal, 25(3/4), 349-359.

Yoshida, D. T., Sandjaya, S., Hirst, G., \& Cooper, B. (2014). Does servant leadership foster creativity and innovation? A multi-level mediation study of identification and prototypicality. Journal of Business Research, 67(7), 1395-1404.

Yupitun, M. A. (2008). Agency trade-offs in family firms: Theoretical model, empirical testing and implications. Theses, 19. 
Figure 1: Conceptual Meta-Model of Family Enterprise Heterogeneity

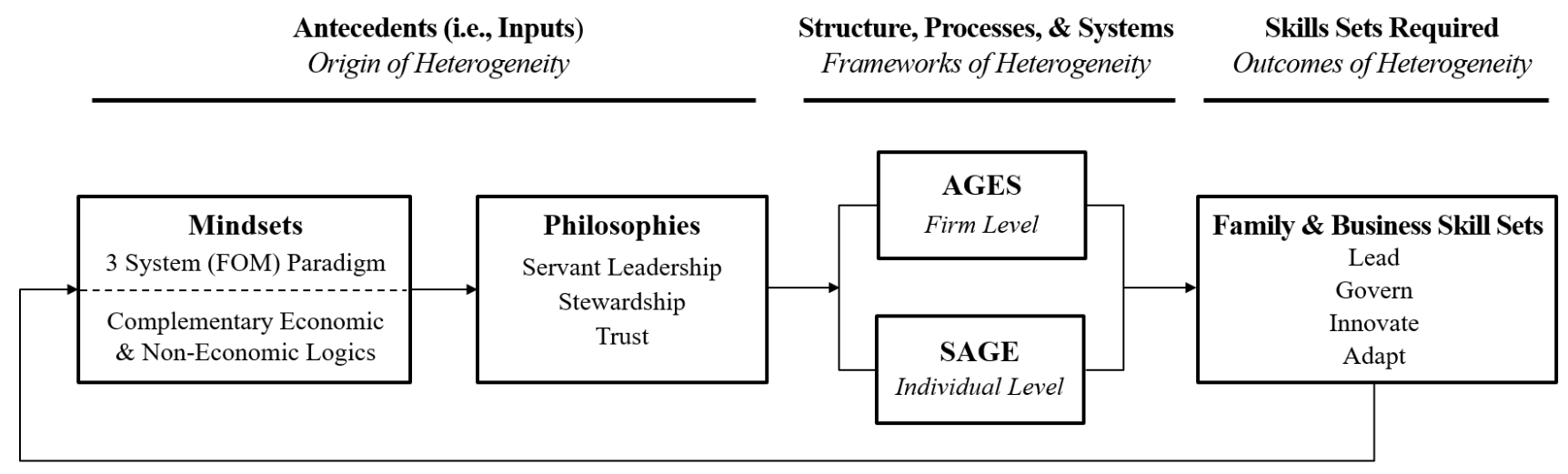


Figure 2: Philosophies Emergent within Family Enterprises

\begin{tabular}{|c|c|}
\hline Philosophies & haracteristic and Description of Each Dimension \\
\hline $\begin{array}{l}\text { Servant Leadership } \\
\text { Behaviors (SQL) } \\
\text { Five Dimensions }\end{array}$ & $\begin{array}{l}\text { 1. Altruistic calling —a desire to make a positive difference in others' lives } \\
\text { 2. Emotional healing — fostering spiritual recovery from hardship or trauma } \\
\text { 3. Wisdom —an awareness of surroundings and anticipation of consequence } \\
\text { 4. Persuasive mapping —influencing others using sound reasoning and mental frameworks to } \\
\text { conceptualize greater possibilities } \\
\text { 5. Organizational stewardship — taking an ethical responsibility for the well-being of the } \\
\text { organization and society. }\end{array}$ \\
\hline $\begin{array}{l}\text { Stewardship Theory } \\
\text { Six Dimensions }\end{array}$ & $\begin{array}{l}\text { 1. Intrinsic motivation-behavior driven by internal rewards, reinforced through opportunities for } \\
\text { personal growth, achievement, affiliation, and self-actualization } \\
\text { 2. Organizational identification - accepting an organization's mission, vision, and objectives, as } \\
\text { well as define oneself by his/her involvement within the organization } \\
\text { 3. Use of personal forms of power - not utilizing one's position of authority to lead but relying on } \\
\text { his/her personal informal power gained through relationships built over time } \\
\text { 4. Collectivism - embracing organizational values and individual behaviors that bind and mutually } \\
\text { obligate individuals to the group } \\
\text { 5. Low power distance - fostering egalitarian interactions, discouraging inequalities, and treating } \\
\text { others equally organizational members without formal titles or authority accept unequal distribution } \\
\text { of power across organizational levels } \\
\text { 6. Involvement orientation - encouraging an inclusive environment that provides employees } \\
\text { autonomy and involvement in decision-making processes results in higher engagement benefiting } \\
\text { the organization and the employees }\end{array}$ \\
\hline $\begin{array}{c}\text { Trust } \\
\text { Four Dimensions }\end{array}$ & $\begin{array}{l}\text { 1. Ability - competence and expertise that enables someone to influence a domain } \\
\text { 2. Benevolence - the extent to which a trustee is believed to want to do good to the trustor } \\
\text { 3. Integrity - the trustor's perception that the trustee adheres to a set of moral principles that the } \\
\text { trustor finds satisfactory } \\
\text { 4. Consistency - the expectation that the trustee will constantly adhere to the same principles }\end{array}$ \\
\hline
\end{tabular}

Source: Adapted servant leadership behaviors from Barbuto and Wheeler (2006); stewardship theory characteristics from Neubaum et al. (2017); and trust dimensions from Mayer, Davis, and Schoorman (1995) and Schoorman, Mayer, and Davis (2007). 
Figure 3: AGES Framework

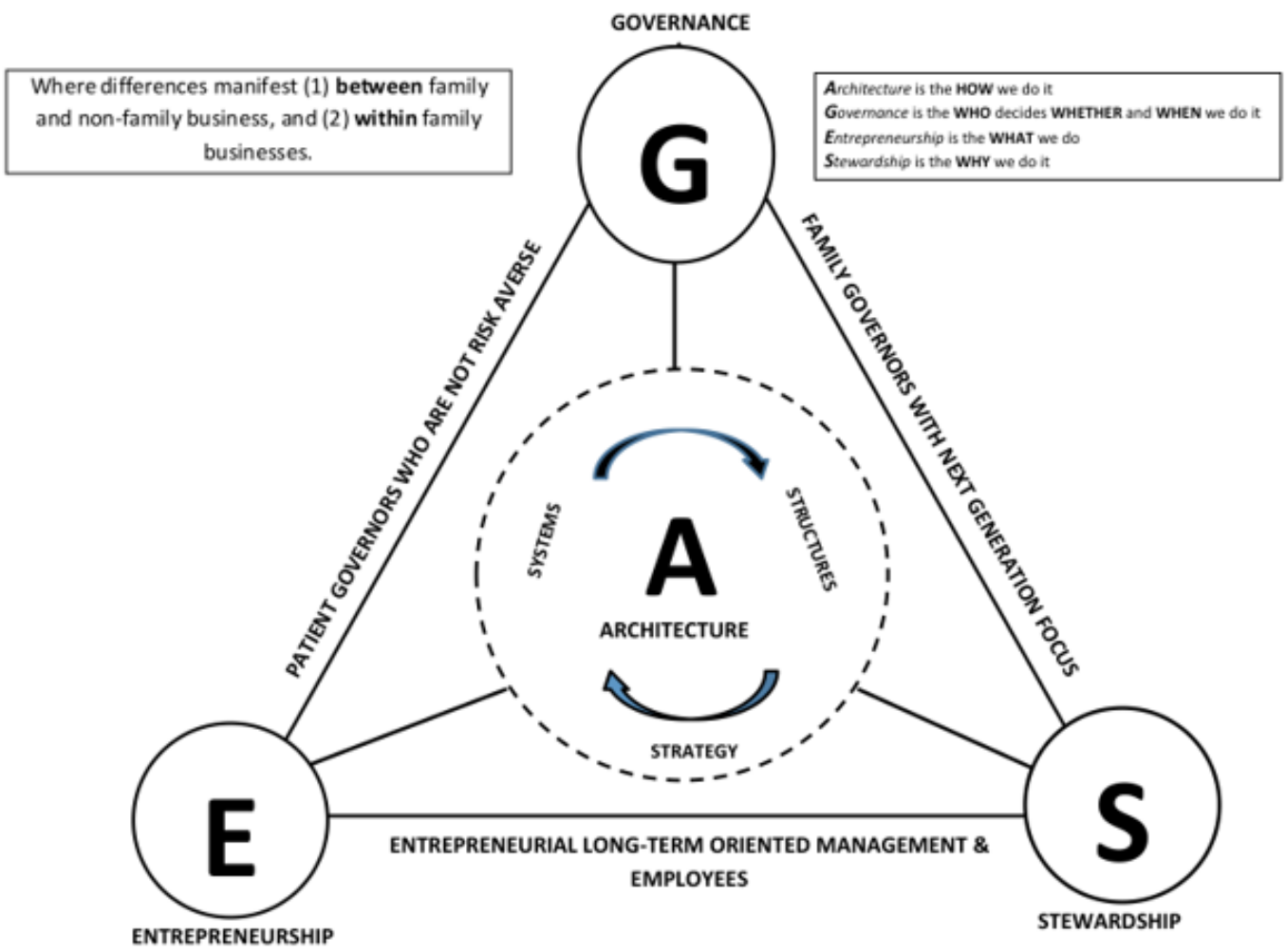

A-GES FAMILY BUSINESS FRAMEWORK (Craig \& Maoro, 2013) 
Figure 4: Perception and Reality of Heterogeneity Grid

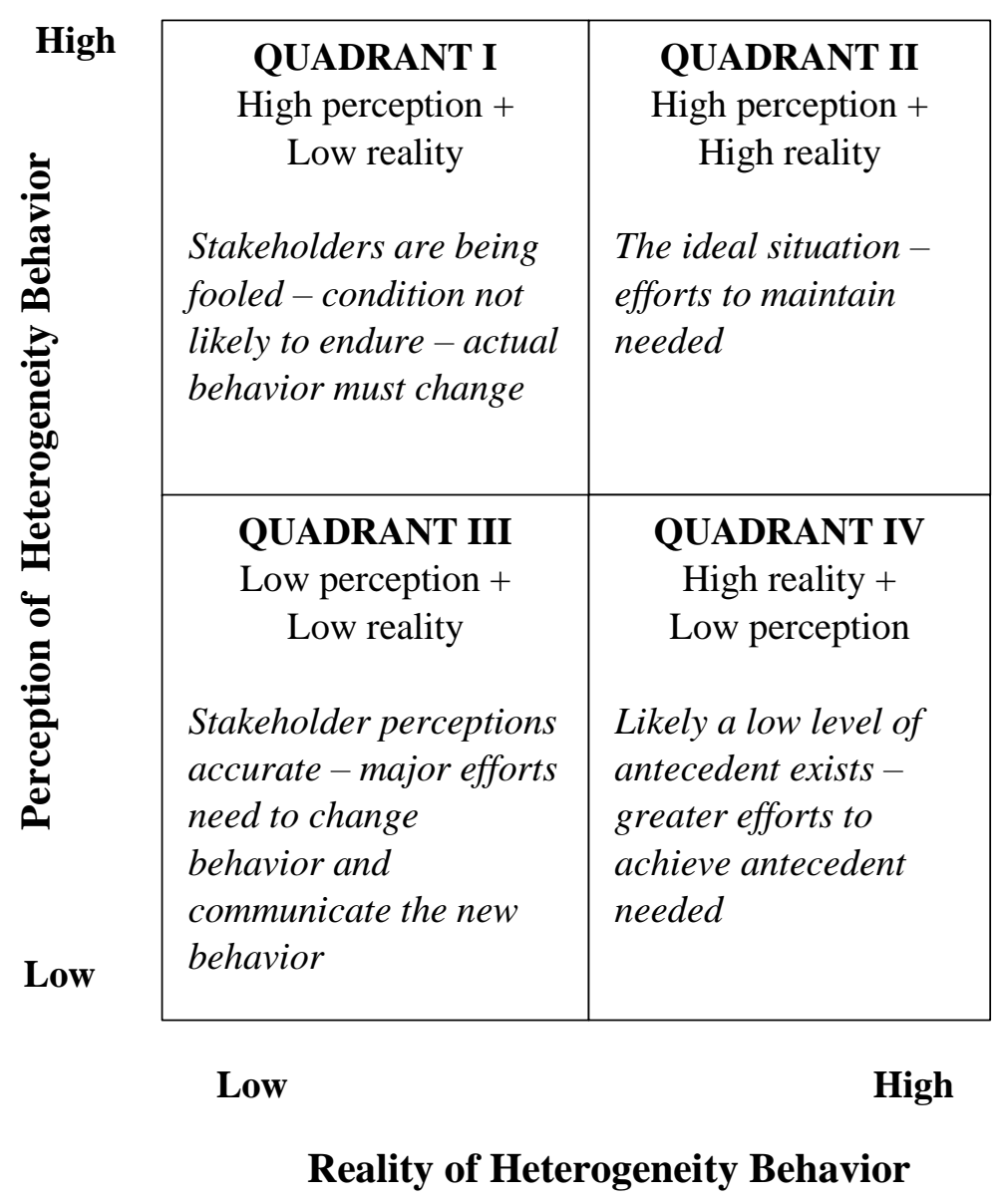

Source: Adapted perception and reality of ethical behavior grid from Parris et al. (2016) 
Table 1: Kuhn's Seven Stages

\begin{tabular}{|c|c|c|}
\hline Stage & Label & Characteristics \\
\hline 1 & Pre-paradigm stage & $\begin{array}{l}\text { During which a body of phenomena is } \\
\text { examined by scientists espousing } \\
\text { competing schools of thought, with no } \\
\text { common body of belief }\end{array}$ \\
\hline 2 & $\begin{array}{l}\text { Development of paradigm } \\
\text { consensus }\end{array}$ & $\begin{array}{l}\text { The emergence of a common body of } \\
\text { belief among practicing scientists within } \\
\text { the field }\end{array}$ \\
\hline 3 & Normal science & $\begin{array}{l}\text { The paradigm is further articulated to } \\
\text { better explain the subject body of } \\
\text { phenomena }\end{array}$ \\
\hline 4 & $\begin{array}{l}\text { Crisis associated with } \\
\text { anomalies }\end{array}$ & $\begin{array}{l}\text { Observable facts are unexplainable within } \\
\text { the existing paradigm }\end{array}$ \\
\hline 5 & A new paradigm & $\begin{array}{l}\text { Appears which is incommensurable with } \\
\text { the old, followed by debates between } \\
\text { advocates on the new paradigm }\end{array}$ \\
\hline 6 & $\begin{array}{l}\text { Resumption of normal science } \\
\text { based upon the new paradigm }\end{array}$ & \\
\hline 7 & Recycling through stages 4 to 7 . & \\
\hline
\end{tabular}

